\title{
Most medical practices are not parachutes: a citation analysis of practices felt by biomedical authors to be analogous to parachutes
}

\author{
Michael J. Hayes MD, Victoria Kaestner BA, Sham Mailankody MBBS, Vinay Prasad MD MPH
}

\section{Abstract}

Background: In a 2003 paper in BMJ, the authors made the tongue-in-cheek observation that there are no randomized controlled trials (RCTs) of parachutes. This paper has been widely read, cited and used to argue that RCTs are impractical or unnecessary for some medical practices. We performed a study to identify and evaluate claims that a medical practice is akin to a parachute.

Methods: Using Google Scholar, we identified all citations to the 2003 paper. We searched for claims that a specific practice was akin to a parachute. For each practice, we identified the desired outcome of the practice, and searched Google Scholar and ClinicalTrials.gov for RCTs that were conducted, ongoing, halted, planned or unpublished.

Results: Of 822 articles citing the original paper, $35(4.1 \%)$ argued that a medical practice was akin to a parachute. Eighteen of the $35(51 \%)$ concerned mortality or live birth, and $17(49 \%)$ concerned a lesser outcome. For 22 practices (63\%), we identified 1 or more RCTs: in 6 cases (27\%), the trials showed a statistically significant benefit of the practice; in $5(23 \%)$, the trials rejected the practice; in $5(23 \%)$, the trials had mixed results; in $2(9 \%)$, the trials were halted; and in $4(18 \%)$, the trials were ongoing. Effect size was calculated for 5 of the 6 practices for which RCTs gave positive results, and the absolute risk reduction ranged from $11 \%$ to $30.8 \%$, corresponding to a number needed to treat of $3-9$.

Interpretation: Although there is widespread interest regarding the BMJ paper arguing that randomized trials are not necessary for practices of clear benefit, there are few analogies in medicine. Most parachute analogies in medicine are inappropriate, incorrect or misused.

I n a widely cited 2003 BMF article, the authors made the tongue-in-cheek observation that there are no randomized trials of parachutes. ${ }^{1}$ In an era in which proponents of evidence-based medicine increasingly rely on randomized controlled trials (RCTs) to show treatment efficacy, Smith and Pell ${ }^{1}$ argued that some medical practices are so beneficial that it would be silly to subject them to an RCT. The use of a parachute during free fall, such as a controlled jump from an airplane, is an example. Without the use of a parachute, the chance of death approaches nearly $100 \%$, although there are scattered case reports of people surviving such a fall. ${ }^{2}$ With a parachute, the risk of death decreases dramatically, with recent estimates of 1.1 deaths per 100000 jumps, a rate of $0.0011 \% .^{3}$ Of course, there are several limits to the parachute analogy in medicine. The first difference is etiology. Falling from an airplane has only 1 causal pathway leading to harm. In contrast, most human diseases have multifactorial etiologies, ${ }^{4}$ and any 1 practice may be unlikely to single-handedly reverse the outcome. The second limitation is the effect size. Parachutes improve survival from nearly $0 \%$ to nearly $100 \%$. Empirical analyses show that few medical practices offer so large a magnitude of benefit. For instance, in a review of over 80000 medical

Competing interests: Sham Mailankody has received honoraria from Wedbush PacGrow for speaking at the annual health care conference and from PleXus Communications for continuing medical education activity. Vinay Prasad is funded by the Laura and John Arnold Foundation. No other competing interests were declared.

This article has been peer reviewed.

Correspondence to: Vinay Prasad, prasad@ohsu.edu

CMAJ Open 2018. DOI:10.9778/cmajo.20170088 
practices from the Cochrane database, Pereira and colleagues $^{5}$ found only 1 medical practice that reliably had a large effect on overall mortality, and the absolute risk reduction (ARR) of this practice was about $33 \% .^{6}$

Despite the limits to the parachute analogy, the article by Smith and Pell ${ }^{1}$ has gained popularity in the medical community and is often used to criticize the need for RCTs of a specific practice. For instance, in a 2016 update to guidelines put forth by the US Department of Agriculture and Department of Health and Human Services, daily flossing was no longer recommended, as it lacked rigorous data showing benefit. ${ }^{7}$ In opposition, Holmes ${ }^{8}$ argued that long-term flossing was akin to a parachute and may not ethically be tested in randomized fashion. Whether daily flossing is a parachute may be debated, and the analogy may be exaggerated. We performed a study to determine how often researchers claim their medical practice is a parachute when it is in fact no such thing.

\section{Methods}

We identified on Google Scholar all articles that cite the paper by Smith and Pell. ${ }^{1}$ Our search was conducted from Jan. 1 to Mar. 31, 2016. We selected Google Scholar because of its extensive citation network and coverage, ${ }^{9}$ which are known to be superior compared to other citation engines, particularly its citation analysis. ${ }^{10,11}$ One reviewer (M.J.H.) screened titles and abstracts of identified articles for full-text review, excluding all articles in languages other than English, published in nonpeer-reviewed journals or not related to human clinical medicine (e.g., veterinary medicine). Selected full-text articles were individually reviewed in full by 2 authors (M.J.H. and V.P); as there were no disagreements, all subsequent analyses were based on the reviews of 1 reviewer (M.J.H.). We included articles that used the paper by Smith and Pell ${ }^{1}$ to argue that a specific medical practice was like a parachute in that it could not ethically or practically be tested in an RCT. We did not include articles that used the paper to argue against the principles of evidence-based medicine in general. We defined a medical practice as any medication, procedure or system-based change intended to help prevent or treat a medical condition.

For all included articles, we searched Medline for RCTs or systematic reviews of RCTs that had investigated the subject referenced by the article. If multiple large RCTs were readily identifiable, they were each included in our analysis. A detailed search strategy for these RCTs is given in Appendix 1 (available at www.cmajopen.ca/content/6/1/E31/suppl/DC1), and all articles selected were reviewed by M.J.H. and V.P. For these RCTs, we ascertained whether studies gave a positive result (net benefit of the proposed practice), negative result (no benefit or net harm of the proposed practice) or mixed result (inconsistent evidence supporting the use of the proposed practice). For practices for which no RCT could be found, we searched ClinicalTrials.gov to identify any ongoing or unpublished RCTs available. For studies with no published or unpublished RCTs, we summarized the nature of the practice, and M.J.H. and V.P. determined whether an RCT was clinically feasible.

\section{Statistical analysis}

We performed descriptive statistics. We calculated the ARR by subtracting the risk in the control arm from that in the experimental arm at whatever time point was reported by the author.

\section{Ethics approval}

This study of published reports did not require institutional board review approval. A protocol can be requested from the corresponding author.

\section{Results}

At the time of our investigation, the article by Smith and Pell ${ }^{1}$ had 822 citations on Google Scholar. Of the 822 articles, 35 (4.3\%) directly compared a medical practice to a parachute or used the parachute argument to defend implementation of that practice (Figure 1). These were included in subsequent analysis. We did not identify any prior citation analyses for the article by Smith and Pell. ${ }^{1}$

Of the 35 medical practices, 22 (63\%) involved RCTs that were completed, ongoing, halted or planned (Table 1). Examples include stenting for renal artery stenosis, insulin analogues for the treatment of type 1 diabetes, simulation training for providers working in critical care medicine and metastasectomy for isolated pulmonary metastatic colorectal cancer. In 6 cases (27\%), RCTs showed a statistically significant benefit of the practice; in $5(23 \%)$, RCTs rejected the practice; in $5(23 \%)$, RCTs gave mixed results; in 2 (9\%),

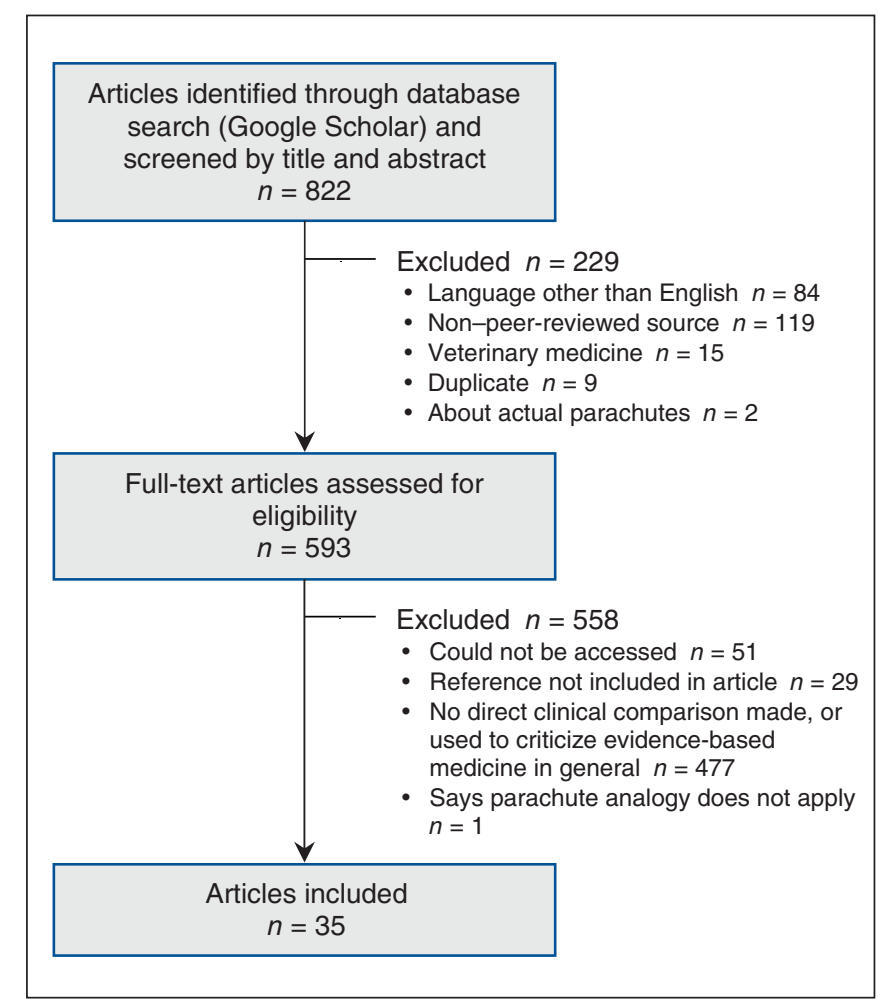

Figure 1: Flow chart showing selection of articles on medical practices analogized to parachutes. 
Table 1 (part 1 of 2): Medical practices analogized to parachutes that have been tested with a randomized controlled trial(s)

\begin{tabular}{|c|c|c|c|c|c|}
\hline Author & Claim & RCT & $\begin{array}{l}\text { Clinical outcome } \\
\text { of medical } \\
\text { practice }\end{array}$ & $\begin{array}{c}\text { Trial } \\
\text { outcome }\end{array}$ & $\begin{array}{l}\text { Magnitude of } \\
\text { benefit/outcome } \\
\text { met in trial }\end{array}$ \\
\hline $\begin{array}{l}\text { Falchook, }{ }^{12} \\
2015\end{array}$ & $\begin{array}{l}\text { Nivolumab for metastatic } \\
\text { melanoma has so impressive a } \\
\text { response rate and progression- } \\
\text { free survival that, akin to a } \\
\text { parachute, examining overall } \\
\text { survival is not necessary }\end{array}$ & $\begin{array}{l}\text { Nivolumab versus } \\
\text { chemotherapy in patients with } \\
\text { advanced melanoma who } \\
\text { progressed after anti-CTLA-4 } \\
\text { treatment (CheckMate 037): a } \\
\text { randomised, controlled, } \\
\text { open-label, phase } 3 \text { trial }^{13} \\
\text { [nivolumab was superior to } \\
\text { decarbazine in CheckMate } 66^{14} \\
\text { (and choice of comparator } \\
\text { seemed a straw man, given year } \\
\text { trial was performed)] }\end{array}$ & $\begin{array}{l}\text { Reduction in } \\
\text { mortality }\end{array}$ & $\begin{array}{l}\text { Supported } \\
\text { practice }\end{array}$ & $\begin{array}{l}\text { 1-yr overall survival } \\
\text { rate increased from } \\
42.1 \% \text { to } 72.9 \% \text {; } \\
\text { ARR } 30.8 \% \text {, NNT } 3\end{array}$ \\
\hline $\begin{array}{l}\text { Schaan et } \\
\text { al. }{ }^{15} 2015\end{array}$ & $\begin{array}{l}\text { Insulin analogues are superior to } \\
\text { regular human insulin for } \\
\text { achieving glycemic control in } \\
\text { type } 1 \text { diabetes }\end{array}$ & $\begin{array}{l}\text { Several, including large } \\
\text { meta-analyses such as } \\
\text { Systematic review and } \\
\text { meta-analysis of short-acting } \\
\text { insulin analogues in patients } \\
\text { with diabetes mellitus }^{16} \text { and } \\
\text { Long-acting insulin analogues } \\
\text { vs. NPH human insulin in type } 1 \\
\text { diabetes. A meta-analysis }{ }^{17}\end{array}$ & $\begin{array}{l}\text { Reduction in } \\
\text { diabetes-related } \\
\text { events } \\
\text { (cardiovascular/ } \\
\text { renal/ocular/ } \\
\text { neurologic) }\end{array}$ & Mixed & - \\
\hline $\begin{array}{l}\text { Montresor et } \\
\text { al. }{ }^{18} 2015\end{array}$ & $\begin{array}{l}\text { Empirical deworming therapy of } \\
\text { children in endemic areas has } \\
\text { clinical benefit }\end{array}$ & $\begin{array}{l}\text { Cochrane reviews of multiple } \\
\text { RCTs, including Deworming } \\
\text { drugs for soil-transmitted } \\
\text { intestinal worms in children: } \\
\text { effects on nutritional indicators, } \\
\text { haemoglobin, and school } \\
\text { performance }^{19}\end{array}$ & $\begin{array}{l}\text { Clearance of } \\
\text { parasites }\end{array}$ & $\begin{array}{l}\text { Refuted } \\
\text { claim }\end{array}$ & - \\
\hline $\begin{array}{l}\text { Luft et al., }{ }^{20} \\
2014\end{array}$ & $\begin{array}{l}\text { Stenting for renal artery stenosis } \\
\text { benefits some patients so greatly } \\
\text { that it is a parachute }\end{array}$ & $\begin{array}{l}\text { Stenting and medical therapy for } \\
\text { atherosclerotic renal-artery } \\
\text { stenosis }^{21}\end{array}$ & $\begin{array}{l}\text { Reduction in } \\
\text { cardiovascular } \\
\text { events }\end{array}$ & $\begin{array}{l}\text { Refuted } \\
\text { claim }\end{array}$ & - \\
\hline $\begin{array}{l}\text { White, }{ }^{22} \\
2011\end{array}$ & $\begin{array}{l}\text { Stenting for renal artery stenosis } \\
\text { benefits some patients so greatly } \\
\text { that it is a parachute }\end{array}$ & $\begin{array}{l}\text { Stenting and medical therapy for } \\
\text { atherosclerotic renal-artery } \\
\text { stenosis }^{21}\end{array}$ & $\begin{array}{l}\text { Reduction in } \\
\text { cardiovascular } \\
\text { events }\end{array}$ & $\begin{array}{l}\text { Refuted } \\
\text { claim }\end{array}$ & - \\
\hline $\begin{array}{l}\text { Bender et } \\
\text { al., }{ }^{23} 2015\end{array}$ & $\begin{array}{l}\text { Simulation-based training for } \\
\text { medical personnel obviously } \\
\text { improves patient outcomes in } \\
\text { critical care medicine }\end{array}$ & $\begin{array}{l}\text { Multiple, including Simulation } \\
\text { improves procedural protocol } \\
\text { adherence during central } \\
\text { venous catheter placement: a } \\
\text { randomized controlled trial }{ }^{24}\end{array}$ & $\begin{array}{l}\text { Reduction in } \\
\text { mortality }\end{array}$ & Mixed & - \\
\hline $\begin{array}{l}\text { Lighthall et } \\
\text { al., }{ }^{25} 2007\end{array}$ & $\begin{array}{l}\text { Simulation-based training for } \\
\text { medical personnel obviously } \\
\text { improves patient outcomes in } \\
\text { critical care medicine }\end{array}$ & $\begin{array}{l}\text { Multiple, including Simulation- } \\
\text { based training of internal } \\
\text { medicine residents in advanced } \\
\text { cardiac life support protocols: a } \\
\text { randomized trial }^{26}\end{array}$ & $\begin{array}{l}\text { Reduction in } \\
\text { mortality }\end{array}$ & Mixed & - \\
\hline $\begin{array}{l}\text { Cefalu et } \\
\text { al., }{ }^{27} 2015\end{array}$ & $\begin{array}{l}\text { Recognition and treatment of } \\
\text { prediabetes leads to improved } \\
\text { patient outcomes }\end{array}$ & $\begin{array}{l}\text { Reduction in the incidence of } \\
\text { type } 2 \text { diabetes with lifestyle } \\
\text { intervention or metformin } 28\end{array}$ & $\begin{array}{l}\text { Reduction in } \\
\text { diabetes-related } \\
\text { events } \\
\text { (cardiovascular/ } \\
\text { renal/ocular/ } \\
\text { neurologic) }\end{array}$ & $\begin{array}{l}\text { Supported } \\
\text { practice }\end{array}$ & $\begin{array}{l}\text { Cumulative } \\
\text { incidence of } \\
\text { diabetes at } 3 \mathrm{yr} \\
\text { decreased from } \\
28.9 \% \text { to } 14.4 \% \text {; } \\
\text { ARR } 14 \%, \text { NNT } 7\end{array}$ \\
\hline $\begin{array}{l}\text { Scheen et } \\
\text { al., }{ }^{29} 2014\end{array}$ & $\begin{array}{l}\text { Treating diabetes with agents } \\
\text { that lower blood glucose will } \\
\text { invariably lead to improved } \\
\text { cardiovascular outcomes }\end{array}$ & $\begin{array}{l}\text { Action to Control Cardiovascular } \\
\text { Risk in Diabetes, }{ }^{30} \text { UK } \\
\text { Prospective Diabetes Study, }{ }^{31} \\
\text { Veterans Affairs Diabetes Trial }{ }^{32}\end{array}$ & $\begin{array}{l}\text { Reduction in } \\
\text { cardiovascular } \\
\text { events }\end{array}$ & $\begin{array}{l}\text { Refuted } \\
\text { claim }\end{array}$ & - \\
\hline $\begin{array}{l}\text { Gleicher et } \\
\text { al., }{ }^{33} 2016\end{array}$ & $\begin{array}{l}\text { Most of current in vitro } \\
\text { fertilization use and application is } \\
\text { so obviously beneficial at } \\
\text { conceiving children it does not } \\
\text { require randomized trials }\end{array}$ & $\begin{array}{l}\text { A multicentre randomized } \\
\text { controlled trial of expectant } \\
\text { management versus IVF in } \\
\text { women with fallopian tube } \\
\text { patency }^{34}\end{array}$ & $\begin{array}{l}\text { Increased rates of } \\
\text { live birth }\end{array}$ & $\begin{array}{l}\text { Supported } \\
\text { practice }\end{array}$ & $\begin{array}{l}\text { Live birth rate } \\
\text { improved from } 1 \% \\
\text { to } 29 \% \text {, ARR } 28 \% \text {, } \\
\text { NNT } 3\end{array}$ \\
\hline
\end{tabular}


Table 1 (part 2 of 2): Medical practices analogized to parachutes that have been tested with a randomized controlled trial(s)

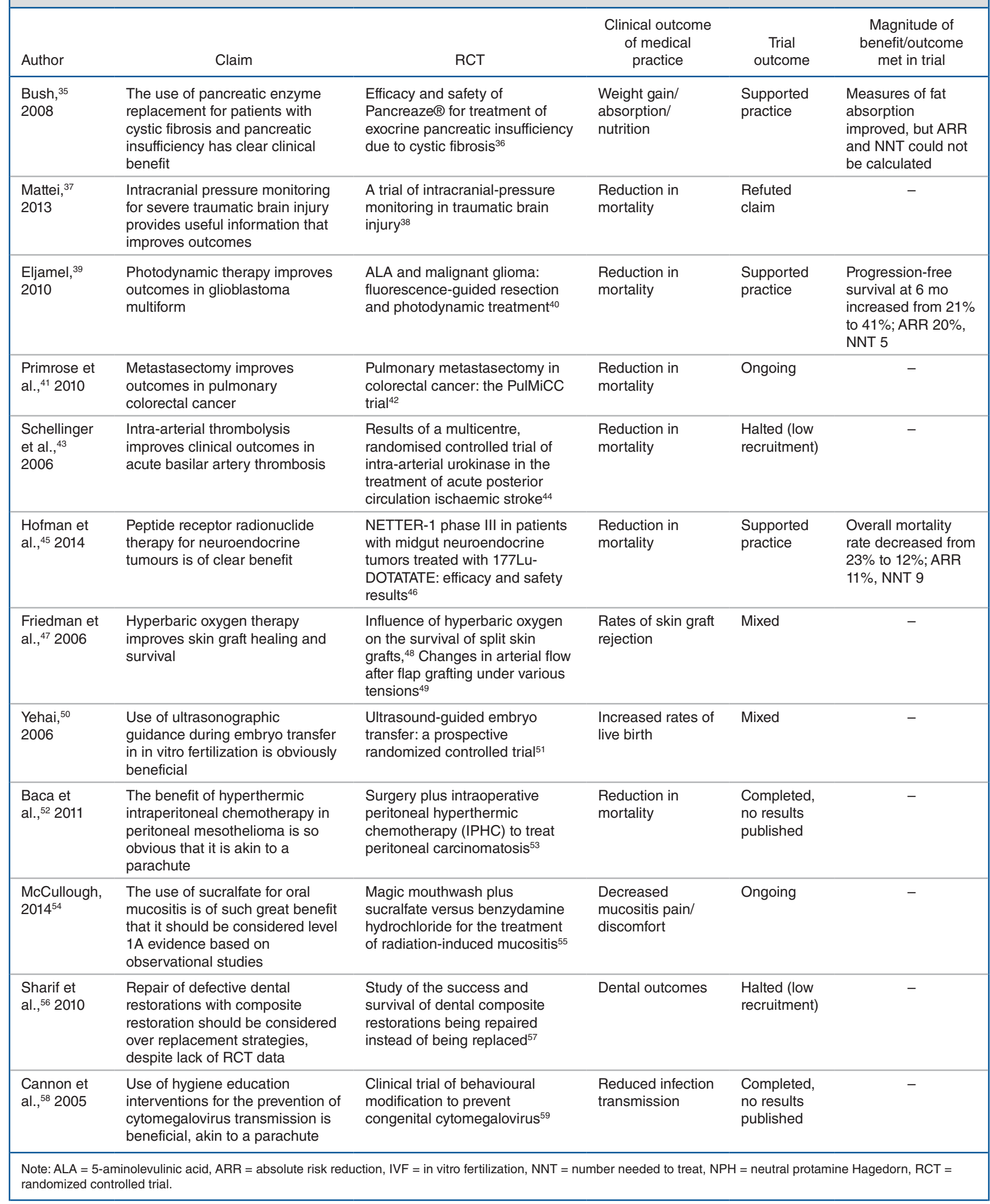


RCTs were halted; and in 4 (18\%), RCTs were ongoing. If mixed data were accepted as showing a significant benefit, 11 practices $(50 \%)$ were supported by identified RCTs.

The remaining 13 medical practices (37\%) had not been tested in an RCT (Table 2). Several are long-standing practices, including mechanical ventilation for acute lung injury, emergency airway management and surgical management of acute epidural hematoma; others are recent practices, such as infection-control strategies for the prevention of perioperative skin and soft-tissue infections, perispinal etanercept administration for poststroke neurologic dysfunction and repair strategies for defective dental restorations.

Table 2: Medical practices analogized to parachutes for which no ongoing or unpublished randomized controlled trial was identified

\begin{tabular}{|c|c|c|c|}
\hline Author & Claim & $\begin{array}{l}\text { Clinical outcome of } \\
\text { medical practice }\end{array}$ & $\begin{array}{c}\text { Practice } \\
\text { could/should } \\
\text { be tested by } \\
\text { RCT }\end{array}$ \\
\hline $\begin{array}{l}\text { Diogo et al., }{ }^{60} \\
2015\end{array}$ & $\begin{array}{l}\text { Having an intensive care unit in a hospital } \\
\text { is of benefit }\end{array}$ & $\begin{array}{l}\text { Reduction in } \\
\text { mortality }\end{array}$ & No \\
\hline $\begin{array}{l}\text { Bryce et al., }{ }^{61} \\
2015\end{array}$ & $\begin{array}{l}\text { Positive results from an observational trial } \\
\text { of nasal photodisinfection and } \\
\text { chlorhexidine wipes for prevention of skin/ } \\
\text { soft-tissue infections are sufficient for } \\
\text { implementation of practice }\end{array}$ & $\begin{array}{l}\text { Reduced skin } \\
\text { infections }\end{array}$ & $\begin{array}{l}\text { Could be } \\
\text { subject to } \\
\text { RCT }\end{array}$ \\
\hline Shah, ${ }^{62} 2015$ & $\begin{array}{l}\text { Endoscopic decompression of } \\
\text { symptomatic cystic duct obstruction is } \\
\text { beneficial, akin to a parachute }\end{array}$ & $\begin{array}{l}\text { Reduction of } \\
\text { symptoms in } \\
\text { symptomatic } \\
\text { gallbladder disease }\end{array}$ & - \\
\hline $\begin{array}{l}\text { Mhyre et al., }{ }^{63} \\
2009\end{array}$ & $\begin{array}{l}\text { Emergency airway management is a form } \\
\text { of "parachute medicine" }\end{array}$ & $\begin{array}{l}\text { Reduction in } \\
\text { mortality }\end{array}$ & - \\
\hline Tsui, ${ }^{64} 2014$ & $\begin{array}{l}\text { The benefit of cerebrospinal fluid lavage } \\
\text { following intrathecal injection of excess or } \\
\text { wrong drugs is so beneficial that it is akin } \\
\text { to a parachute }\end{array}$ & $\begin{array}{l}\text { Reduction in } \\
\text { mortality }\end{array}$ & - \\
\hline Seto et al., ${ }^{65} 2015$ & $\begin{array}{l}\text { The use of covered stents for coronary } \\
\text { artery perforation is beneficial, despite lack } \\
\text { of RCT data }\end{array}$ & $\begin{array}{l}\text { Reduction in } \\
\text { mortality }\end{array}$ & - \\
\hline $\begin{array}{l}\text { Nelson et al. }{ }^{66} \\
2014\end{array}$ & $\begin{array}{l}\text { Surgical management of acute epidural } \\
\text { hematoma is beneficial, despite lack of } \\
\text { RCT data }\end{array}$ & $\begin{array}{l}\text { Reduction in } \\
\text { mortality }\end{array}$ & - \\
\hline $\begin{array}{l}\text { Ignatowski et al., }{ }^{67} \\
2014\end{array}$ & $\begin{array}{l}\text { Perispinal etanercept in the setting of } \\
\text { poststroke neurologic dysfunction has } \\
\text { therapeutic benefit, despite lack of RCT } \\
\text { data }\end{array}$ & $\begin{array}{l}\text { Reduction of } \\
\text { neurologic and } \\
\text { cognitive } \\
\text { dysfunction }\end{array}$ & $\begin{array}{l}\text { Could be } \\
\text { subject to } \\
\text { RCT }\end{array}$ \\
\hline Evers, ${ }^{68} 2013$ & $\begin{array}{l}\text { In vitro fertilization is effective in couples } \\
\text { without a chance of spontaneous } \\
\text { pregnancy, akin to a parachute }\end{array}$ & $\begin{array}{l}\text { Increased rates of } \\
\text { live birth }\end{array}$ & - \\
\hline Harbarth, ${ }^{69} 2013$ & $\begin{array}{l}\text { Requiring short fingernails among } \\
\text { providers will decrease rates of infection } \\
\text { transmission }\end{array}$ & $\begin{array}{l}\text { Reduction in } \\
\text { infection } \\
\text { transmission }\end{array}$ & $\begin{array}{l}\text { Could be } \\
\text { subject to } \\
\text { RCT }\end{array}$ \\
\hline North et al., ${ }^{70} 2014$ & $\begin{array}{l}\text { Use of new adhesive for spinal cord } \\
\text { stimulator implantation was effective and } \\
\text { can be safely implemented under guise of } \\
\text { "mechanism-based medicine," akin to a } \\
\text { parachute }\end{array}$ & $\begin{array}{l}\text { Reduced stimulator } \\
\text { lead migration }\end{array}$ & $\begin{array}{l}\text { Could be } \\
\text { subject to } \\
\text { RCT }\end{array}$ \\
\hline Landucci, ${ }^{71} 2004$ & $\begin{array}{l}\text { Mechanical ventilation in lung injury is } \\
\text { beneficial }\end{array}$ & $\begin{array}{l}\text { Reduction in } \\
\text { mortality }\end{array}$ & - \\
\hline Sennerby, ${ }^{72} 2000$ & $\begin{array}{l}\text { Osseointegrated dental implants are } \\
\text { beneficial for treating total or partial } \\
\text { edentulism, akin to a parachute }\end{array}$ & Dental outcomes & - \\
\hline
\end{tabular}




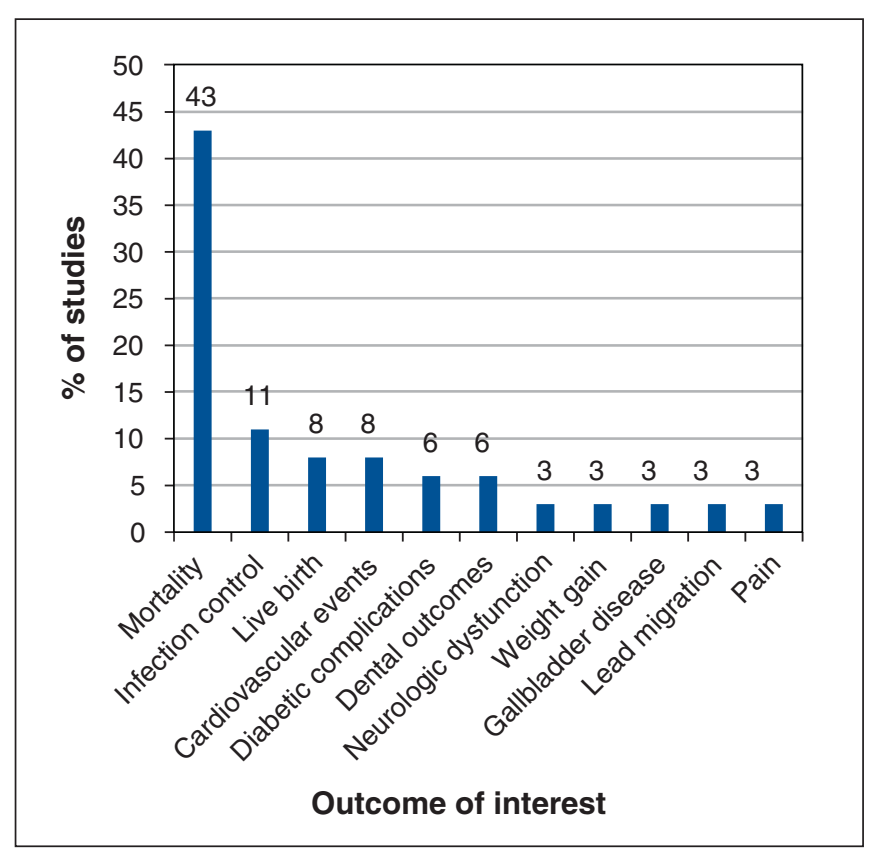

Figure 2: Outcome of interest for medical practices analogized to parachutes.

Mortality or live birth was the clinical outcome of interest for $18 / 35$ practices (51\%). A lesser outcome, including infection control, reduced diabetic complications, cardiovascular events, clearance of parasites, pain or discomfort, weight gain, lead migration and effective dental restoration, was the outcome of interest for the remaining 17 practices (49\%) (Figure 2).

Among the 6 practices with positive evidence in RCTs, the ARR could be calculated for 5 and ranged from $11 \%$ to $30.8 \%$, corresponding to a number needed to treat (NNT) of $3-9$. Notably, 3 of the 5 studies concerned mortality or live birth, and 2 reported the ARR for other outcomes.

\section{Interpretation}

Over a decade after publication of the article by Smith and Pell, ${ }^{1}$ which concluded that RCTs of parachutes or other highly effective practices would be ludicrous, we found few papers citing the article that argued that a medical practice is a parachute. Among those practices, only half referred to a practice whose clinical outcome was mortality or live birth. Of identified practices, more than half have been tested in an RCT, which undermines the claim that the practice is a parachute. Among the remaining practices, RCTs seem possible, even desirable, for several.

In this respect, our findings are similar to those of other empirical analyses. Glasziou and colleagues ${ }^{73}$ compiled a list $^{2}$ of 16 examples of treatments that are universally considered beneficial and that lack randomized study. Djulbegovic ${ }^{74}$ extended this list to nearly 50 examples. Yet what must be acknowledged is that this set of interventions is a tiny fraction of all medical practices: as there are at least 80000 practices, ${ }^{5}$ 50 practices account for just $0.06 \%$ of medical interventions.
The proportion of purported parachutes for which RCTs gave a positive result in our study, $50 \%$ if mixed trial results are interpreted as positive, is similar to the reported rate of trials with positive results in the setting of genuine therapeutic uncertainty, just over $50 \% .{ }^{75}$ This suggests that analogizing a medical practice to a parachute is done for practices that are, on average, no more likely to be beneficial than a typical medical practice tested in randomized fashion.

Moreover, previous parachutes in medicine have been shown to be overstated. The philosopher of science John Worrall commented, after listing several medical treatments, including appendectomy for acute appendicitis, "no RCT has ever been performed on any of these treatments and none presumably ever will." ${ }^{76}$ Yet there are now 4 RCTs of appendectomy versus antibiotics, ${ }^{77-80}$ which suggests that there may be a subset of patients who can be spared surgery. Another example is precision oncology. Experts have claimed that the use of next-generation sequencing to pair patients with cancer with targeted therapies is a medical practice of such great promise that RCTs are unethical. ${ }^{81}$ To date, 1 RCT has been conducted for this practice, yielding negative results. ${ }^{82}$ In both of these cases, the presence of a RCT, particularly one that gives a negative result, undermines the parachute analogy.

In cases in which the magnitude of benefit was estimable, we found NNT values of 3-9 and ARR values of $11 \%-30.8 \%$. These gains are smaller than those with parachutes, which have ARR values greater than $99 \%$ and NNT values approaching 1 . These results suggest that, even when RCTs support the use of the practice, the use of the parachute analogy is inappropriate.

Although more RCTs are being performed per annum than ever before, ${ }^{83}$ the idea of the RCT as the pinnacle of evidence-based medicine has been criticized. ${ }^{84}$ Moreover, there is growing interest in the use of observational data, including big data and real-world data, to make causal inferences about the efficacy of novel treatments. ${ }^{85,86}$ One justification for this interest is that it may not be feasible or ethical to conduct RCTs for highly promising medical practices. Our results provide a reassuring note. Few medical practices have large treatment effects, ${ }^{5}$ and even practices believed to be parachutes often are not.

\section{Limitations}

Although we performed an exhaustive search of references to the seminal paper by Smith and Pell ${ }^{1}$ using a search engine with the widest citation network, ${ }^{10,11}$ we may not have captured all instances in which researchers likened a particular practice to a parachute, as many such instances may not have been captured by the use of a single search engine or may have predated the 2003 paper.

Second, and notably, only a small proportion of papers citing the article by Smith and Pell ${ }^{1}$ drew a specific comparison to a medical practice. This is largely in part because many researchers cite the paper to criticize generally the importance of RCTs. Nevertheless, this fact is also noteworthy. In over a decade since publication of the article, and although it has generated widespread discussion and interest, few citing papers argue that a practice in medicine is akin to a parachute. 
Third, our paper does not imply that RCTs are always feasible, possible, necessary or ethical. We tried to be as objective as possible in our determination of which practices could be tested in RCTs in the future, but we acknowledge the subjective nature of this assessment and the inherent challenges of performing rigorous RCTs. In fact, it is inevitable that there will be situations in medicine in which decisions have to be made in the absence of randomized data. ${ }^{87}$ Moreover, as noted by Djulbegovic, ${ }^{74}$ there are indeed examples of practices universally thought beneficial in the absence of RCTs. However, our investigation provides further evidence that the number of such practices is few. We also provide a cautionary note: a researcher's belief that an intervention is a parachute seems a poor predictor of actual parachute practices.

\section{Conclusion}

Although there is widespread interest in the idea that some medical practices are like parachutes - with a magnitude of benefit so large and obvious that RCTs are unnecessary few biomedical authors compare a specific medical practice to a parachute. When they do, over half refer to a practice that has been tested with an RCT, and half refer to an outcome of lesser importance than overall survival, findings that undermine the claim that the practice is a parachute. When RCTs have been conducted and estimate effect sizes, practices analogized to parachutes have ARR values that are smaller and NNT values that are larger than those for parachutes. Although we found that the parachute analogy is seldom used to describe a medical practice, when it is used it is often inappropriate, incorrect or misused.

\section{References}

1. Smith GC, Pell JP. Parachute use to prevent death and major trauma related to gravitational challenge: systematic review of randomised controlled trials. $B M 7$ 2003;327:1459-61.

2. Cunningham A. A highest fall survived without a parachute. In: Guinness World Records 2002. London (UK): Guinness World Records; 2001.

3. Injury/fatality rates. Leicester (UK): British Parachute Association; 2007. Available: www.bpa.org.uk/staysafe/how-safe/ (accessed 2016 Apr. 17).

4. Hook CC, DiMagno EP, Tefferi A. Primer on medical genomics. Part XIII: Ethical and regulatory issues. Mayo Clin Proc 2004;79:645-50.

5. Pereira TV, Horwitz RI, Ioannidis JP. Empirical evaluation of very large treatment effects of medical interventions. 7AMA 2012;308:1676-84

6. Mugford M, Elbourne D, Field D. Extracorporeal membrane oxygenation for severe respiratory failure in newborn infants. Cocbrane Database Syst Rev 2008; (3):CD001340.

7. Saint Louis C. Feeling guilty about not flossing? Maybe there's no need. The New York Times 2016 Aug. 2.

8. Holmes J. Flossing and the art of scientific investigation. The New York Times [Sunday Review] 2016 Nov. 25.

9. Gehanno JF, Rollin L, Darmoni S. Is the coverage of Google Scholar enough to be used alone for systematic reviews. BMC Med Inform Decis Mak 2013; $13: 7$.

10. Harzing AWK, van der Wal R. Google Scholar as a new source for citation analysis. Ethics Sci Environ Polit 2008;8:61-73.

11. Kousha K, Thelwall M. Google Scholar citations and Google Web/URL citations: a multi-discipline exploratory analysis. 7 Assoc Inf Sci Technol 2007;58: 1055-65

12. Falchook G. Nivolumab: another weapon in the growing immunotherapy arsenal. Lancet Oncol 2015;16:350-1.

13. Weber JS, D'Angelo SP, Minor D, et al. Nivolumab versus chemotherapy in patients with advanced melanoma who progressed after anti-CTLA-4 treatment (CheckMate 037): a randomised, controlled, open-label, phase 3 trial. Lancet Oncol 2015;16:375-84.

14. Robert C, Long GV, Brady B, et al. Nivolumab in previously untreated melanoma without BRAF mutation. N Engl 7 Med 2015;372:320-30.
15. Schaan BD, Scheffel RS. Modern insulins, old paradigms and pragmatism: choosing wisely when deciding how to treat type 1 diabetes. Diabetol Metab Syndr 2015;7:35.

16. Plank J, Siebenhofer A, Berghold A, et al. Systematic review and meta-analysis of short-acting insulin analogues in patients with diabetes mellitus. Arch Intern Med 2005;165:1337-44.

17. Monami M, Marchionni N, Mannucci E. Long-acting insulin analogues vs. NPH human insulin in type 1 diabetes. A meta-analysis. Diabetes Obes Metab 2009; 11:372-8.

18. Montresor A, Addiss D, Albonico M, et al. Methodological bias can lead the Cochrane Collaboration to irrelevance in public health decision-making. PLoS Negl Trop Dis 2015;(9):e0004165.

19. Taylor-Robinson DC, Maayan N, Soares-Weiser K, et al. Deworming drugs for soil-transmitted intestinal worms in children: effects on nutritional indicators, haemoglobin, and school performance. Cochrane Database Syst Rev 2015; (7):CD000371.

20. Luft FC, Safak E, Dechend R. Gunfight at O.K. CORAL. 7 Am Soc Hypertens 2014;8:276-80.

21. Cooper CJ, Murphy TP, Cutlip DE, et al. Stenting and medical therapy for atherosclerotic renal-artery stenosis. N Engl 7 Med 2014;370:13-22

22. White CJ. The need for randomized trials to prove the safety and efficacy of parachutes, bulletproof vests, and percutaneous renal intervention. Mayo Clin Proc 2011;86:603-5.

23. Bender SP, Hamlin M. Simulation: Why not, when it feels so good? Crit Care Med 2015;43:254-5.

24. Peltan ID, Shiga T, Gordon JA, et al. Simulation improves procedural protocol adherence during central venous catheter placement: a randomized controlled trial. Simul Healthc 2015; 10:270-6.

25. Lighthall GK, Barr J. The use of clinical simulation systems to train critical care physicians. F Intensive Care Med 2007;22:257-69.

26. Wayne DB, Butter J, Siddall VJ, et al. Simulation-based training of internal medicine residents in advanced cardiac life support protocols: a randomized trial. Teach Learn Med 2005;17:210-6.

27. Cefalu WT, Petersen MP, Ratner RE. Response to comment on Cefalu et al. The alarming and rising costs of diabetes and prediabetes: a call for action! Diabetes Care 2014;37:3137-3138. Diabetes Care 2015;38:e82-3.

28. Knowler WC, Barrett-Connor E, Fowler SE, et al. Reduction in the incidence of type 2 diabetes with lifestyle intervention or metformin. N Engl 7 Med 2002; 346:393-403.

29. Scheen AJ, Charbonnel B. Effects of glucose-lowering agents on vascular outcomes in type 2 diabetes: a critical reappraisal. Diabetes Metab 2014;40: 176-85.

30. Gerstein HC, Miller ME, Byington RP, et al.; ACCORD Investigators. Effects of intensive glucose lowering in type 2 diabetes. $N$ Engl 7 Med 2008;358: 2545-59.

31. Intensive blood-glucose control with sulphonylureas or insulin compared with conventional treatment and risk of complications in patients with type 2 diabetes (UKPDS 33). UK Prospective Diabetes Study (UKPDS) Group. [Published erratum in Lancet 1999;354:602] Lancet 1998;352:837-53.

32. Duckworth W, Abraira C, Moritz T, et al.; VADT Investigators. Glucose control and vascular complications in veterans with type 2 diabetes. $N$ Engl $7 \mathrm{Med}$ 2009;360:129-39.

33. Gleicher N, Kushnir VA, Barad DH. Why prospectively randomized clinical trials have been rare in reproductive medicine and will remain so. Reprod Sci 2016;23:6-10.

34. Hughes EG, Beecroft ML, Wilkie V, et al. A multicentre randomized controlled trial of expectant management versus IVF in women with fallopian tube patency. Hum Reprod 2004;19:1105-9.

35. Bush A. Editorial overview: newborn screening for cystic fibrosis - Benefit or bane? Paediatr Respir Rev 2008;9:301-2.

36. Trapnell BC, Strausbaugh SD, Woo MS, et al. Efficacy and safety of PANCREAZE® for treatment of exocrine pancreatic insufficiency due to cystic fibrosis. 7 Cyst Fibros 2011;10:350-6.

37. Mattei TA. Intracranial pressure monitoring in severe traumatic brain injury: Who is still bold enough to keep sinning against the level I evidence? World Neurosurg 2013;79:602-4.

38. Chesnut RM, Temkin N, Carney N, et al. A trial of intracranial-pressure monitoring in traumatic brain injury. N Engl 7 Med 2012;367:2471-81.

39. Eljamel S. Photodynamic applications in brain tumors: a comprehensive review of the literature. Photodiagnosis Photodyn Ther 2010;7:76-85.

40. Stepp H, Beck T, Pongratz T, et al. ALA and malignant glioma: fluorescenceguided resection and photodynamic treatment. 7 Environ Pathol Toxicol Oncol 2007;26:157-64.

41. Primrose J, Treasure T, Fiorentino F. Lung metastasectomy in colorectal cancer: Is this surgery effective in prolonging life? Respirology 2010;15:742-6.

42. Treasure T, Fallowfield L, Lees B, et al. Pulmonary metastasectomy in colorectal cancer: the PulMiCC trial. Thorax 2012;67:185-7.

43. Schellinger PD, Hacke W. Intra-arterial thrombolysis is the treatment of choice for basilar thrombosis. Stroke 2006;37:2436-7.

44. Macleod MR, Davis SM, Mitchell PJ, et al. Results of a multicentre, randomised controlled trial of intra-arterial urokinase in the treatment of acute posterior circulation ischaemic stroke. Cerebrovasc Dis 2005;20:12-7. 
45. Hofman MS, Hicks RJ. Peptide receptor radionuclide therapy for neuroendocrine tumours: Standardized and randomized, or personalized? Eur 7 Nucl Med Mol Imaging 2014;41:211-3.

46. NETTER-1 phase III in patients with midgut neuroendocrine tumors treated with 177Lu-DOTATATE: efficacy and safety results. Clin Adv Hematol Oncol 2016;14(Suppl 7):8-9

47. Friedman HI, Fitzmaurice M, Lefaivre JF, et al. An evidence-based appraisal of the use of hyperbaric oxygen on flaps and grafts. Plast Reconstr Surg 2006;117 (Suppl 7):175S-90S; discussion 191S-2S.

48. Perrins DJ. Influence of hyperbaric oxygen on the survival of split skin grafts. Lancet 1967;1:868-71.

49. Xie ZX, Li CY. Changes in arterial flow after flap grafting under various tensions. Clin Rebabil Tissue Eng Res 2007;11:5004-5.

50. Yehai M. Embryo transfer: Does ultrasound guidance make a difference? Middle East Fertil Soc 7 2006;11:173-82.

51. Tang OS, Ng EH, So WW, et al. Ultrasound-guided embryo transfer: a prospective randomized controlled trial. Hum Reprod 2001;16:2310-5.

52. Baca JM, Chiara JA, Strenge KS, et al. Small-cell carcinoma of the parotid gland. 7 Clin Oncol 2011;29:e34-6.

53. Wuhan University. Surgery plus intraoperative peritoneal hyperthermic chemotherapy (IPHC) to treat peritoneal carcinomatosis. ClinicalTrials.gov: NCT00454519; 2009. Available: https://clinicaltrials.gov/ct2/results? cond=\& term $=00454519 \&$ cntry $=\&$ state $=\&$ city $=\&$ dist $=($ accessed 2016 Mar. 1$)$.

54. McCullough RW. New category of evidence should permit the multinational association of support in cancer care (MASCC) to review polymerized crosslinked sucralfate paste (ProThelial ${ }^{\mathrm{TM}}$ ) for mucositis guidelines. Oncol Discov 2014;2.1. doi:10.7243/2052-6199-2-1.

55. Juravinski Cancer Centre Foundation. Magic mouthwash plus sucralfate versus benzydamine hydrochloride for the treatment of radiation-induced mucositis. ClinicalTrials.gov: NCT00814359; 2011. Available: https://clinicaltrials.gov/ct2/ show/record/NCT00814359? term=sucralfate \& cond=Mucositis\&rank=1 (accessed 2017 Oct. 19).

56. Sharif MO, Catleugh M, Merry A, et al. Replacement versus repair of defective restorations in adults: resin composite. Cochrane Database Syst Rev 2014;(2): CD005971.

57. Dalhousie University. Study of the success and survival of dental composite restorations being repaired instead of being replaced. ClinicalTrials.gov: NCT02046109; 2016. Available: https://clinicaltrials.gov/ct2/show/ NCT02046109? term=dental+restoration+repair+replacement\&rank=4 (accessed 2017 Oct. 19)

58. Cannon MJ, Davis KF. Washing our hands of the congenital cytomegalovirus disease epidemic. BMC Public Health 2005;5:70.

59. Women and Infants Hospital of Rhode Island. Clinical trial of behavioral modification to prevent congenital cytomegalovirus. ClinicalTrials.gov: NCT01819519; 2015. Available: https://clinicaltrials.gov/ct2/show/NCT01819519?term=hygiene \& cond $=C M V \&$ rank $=1$ (accessed 2017 Oct. 19)

60. Diogo LP, Bahlis LF, Wajner A, et al. Decreased mortality in patients hospitalized due to respiratory diseases after installation of an intensive care unit in a secondary hospital in the interior of Brazil. Rev Bras Ter Intensiva 2015;27: 235-9.

61. Bryce E, Wong T, Forrester L, et al. Reply to: Nasal photodisinfection and chlorhexidine: Post hoc ergo propter hoc? (f Hosp Infect 2015;90:83-84). 7 Hosp Infect 2015;91:374-5.

62. Shah RJ. Endoscopic gallbladder drainage in medically inoperable patients with symptomatic cholelithiasis: A tube to avoid "going down the tubes"? Dig Dis Sci 2015;60:2228-9.

63. Mhyre JM, Martin LD, Ramachandran SK, et al. Is faculty presence during emergent tracheal intubation justified? Anesthesiology 2009;111:217-8.

64. Tsui BC. Common sense medicine and cerebrospinal lavage. Anaesthesia 2014; 69:936-7.

65. Seto AH, Kern MJ. Coronary perforation: What color is your parachute? Catheter Cardiovasc Interv 2015;86:405-6.

66. Nelson KS, Brearley AM, Haines SJ. Evidence-based assessment of wellestablished interventions: the parachute and the epidural hematoma. Neurosurgery 2014;75:552-9, discussion 559.

67. Ignatowski TA, Spengler RN, Tobinick E. Authors' reply to Whitlock: Perispinal etanercept for post-stroke neurological and cognitive dysfunction: scientific rationale and current evidence. CNS Drugs 2014;28:1207-13.

68. Evers JL. The wobbly evidence base of reproductive medicine. Reprod Biomed Online 2013;27:742-6.
69. Harbarth S. What can we learn from each other in infection control? Experience in Europe compared with the USA. 7 Hosp Infect 2013;83:173-84.

70. North RB, Recinos VR, Attenello FJ, et al. Prevention of percutaneous spinal cord stimulation electrode migration: a 15 -year experience. Neuromodulation 2014;17:670-6, discussion 676-7.

71. Landucci D. The surviving sepsis guidelines: "lost in translation." Crit Care Med 2004;32:1598-600.

72. Sennerby L. Dental implants: matters of course and controversies. Periodontol 2000 2008;47:9-14.

73. Glasziou P, Chalmers I, Rawlins $M$, et al. When are randomised trials unnecessary? Picking signal from noise. BM7 2007;334:349-51.

74. Djulbegovic B. Non-randomized trials that changed medical practice. Tampa: University of South Florida, Tampa. Available: http://personal.health.usf.edu/ bdjulbeg/oncology/NON-RCT-practice-change.htm (accessed 2016 June 1).

75. Djulbegovic B, Kumar A, Glasziou P, et al. Medical research: trial unpredictability yields predictable therapy gains. Nature 2013;500:395-6.

76. Worrall J. Evidence in medicine and evidence-based medicine. Philos Compass 2007;2:981-1022.

77. Hansson J, Korner U, Khorram-Manesh A, et al. Randomized clinical trial of antibiotic therapy versus appendicectomy as primary treatment of acute appendicitis in unselected patients. Br 7 Surg 2009;96:473-81.

78. Vons C, Barry C, Maitre S, et al. Amoxicillin plus clavulanic acid versus appendicectomy for treatment of acute uncomplicated appendicitis: an open-label, non-inferiority, randomised controlled trial. Lancet 2011;377:1573-9.

79. Styrud J, Eriksson S, Nilsson I, et al. Appendectomy versus antibiotic treatment in acute appendicitis. a prospective multicenter randomized controlled trial. World 7 Surg 2006;30:1033-7.

80. Eriksson S, Granstrom L. Randomized controlled trial of appendicectomy versus antibiotic therapy for acute appendicitis. Br 7 Surg 1995;82:166-9.

81. Chasing cancer - the hope versus the hype [video]. The Washington Post Live 2016 Dec. 6.

82. Le Tourneau C, Delord JP, Gonçalves A, et al. Molecularly targeted therapy based on tumour molecular profiling versus conventional therapy for advanced cancer (SHIVA): a multicentre, open-label, proof-of-concept, randomised, controlled phase 2 trial. Lancet Oncol 2015;16:1324-34.

83. Heneghan C. How many randomized trials are published each year [blog]? Oxford (UK): TrustTheEvidence.net [Centre for Evidence Based Medicine Department of Primary Care]; 2010. Available: http://blogs.trusttheevidence. net/carl-heneghan/how-many-randomized-trials-are-published-each-year (accessed 2016 June 1).

84. Bothwell LE, Greene JA, Podolsky SH, et al. Assessing the gold standard lessons from the history of RCTs. N Engl f Med 2016;374:2175-81.

85. Sherman RE, Anderson SA, Dal Pan GJ, et al. Real-world evidence - What is it and what can it tell us? N Engl 7 Med 2016;375:2293-7.

86. Califf RM, Robb MA, Bindman AB, et al. Transforming evidence generation to support health and health care decisions. NEngl f Med 2016;375:2395-400.

87. Prasad VK, Cifu AS. Ending medical reversal: improving outcomes, saving lives. Baltimore (MD): Johns Hopkins University Press; 2015.

Affiliations: Division of Internal Medicine (Hayes); Division of Hematology and Medical Oncology (Kaestner, Prasad), Knight Cancer Institute, Oregon Health and Science University, Portland, Ore.; Division of Myeloma (Mailankody), Memorial Sloan Kettering Cancer Center, New York, NY; Department of Preventive Medicine and Public Health (Prasad); Center for Health Care Ethics (Prasad), Oregon Health and Science University, Portland, Ore.

Contributors: Vinay Prasad conceived and designed the study. Michael Hayes acquired and analyzed the data. Victoria Kaestner contributed to data acquisition and assembly. Sham Mailankody and Victoria Kaestner contributed to data analysis and interpretation. Vinay Prasad and Michael Hayes drafted the manuscript. All of the authors revised the work for important intellectual content, gave final approval of the version to be published and agreed to be accountable for all aspects of the work.

Supplemental information: For reviewer comments and the original submission of this manuscript, please see www.cmajopen.ca/content/6/1/ E31/suppl/DC1. 